\title{
Dealing with conflicts between conservation and socioeco- nomic activities. A social perception study in the Costa Brava, Spain.
}

\author{
Elisabet Roca,Department of Transport Infrastructure and Territory, Technical University of Catalonia, \\ Elisabet.roca@upc.edu \\ Míriam Villares, Department of Transport Infrastructure and Territory, Technical University of Catalonia, \\ Miriam.villares@upc.edu \\ Elisabeth Fernández, Geography Department, University of Las Palmas de Gran Canaria efernan- \\ dez@becarios.ulpgc.es
}

\begin{abstract}
The conflicts between different users are frequent in the cases when conservation plans affect agricultural land uses. The main objective of this paper is to explore public perceptions to plans to protect natural areas. This research has been carried out in the designated area of Aiguamolls de l'Empordà, in the heart of Costa Brava, Spain where a proposal to extend the perimeter of the protected area has created a local but severe social conflict. A social perception study based on a qualitative survey with local stakeholders has been carried out to collect the local opinion on the issue and the perception with regard to the socioeconomic and environmental impacts of planning strategy.
\end{abstract}

Essentially, the intervention is felt to be a threat to the future of several socioeconomic activities (i.e. agriculture, campsites). Moreover, mistrust of the public administration has produced the emergence of an old conflict. The authors argue that the assessment of problems and conflicts affecting coasts have lacked from an in-depth understanding of the social dimension. Therefore, analysing perceptions and attitudes to strategies and management practices can produce relevant information to improve the management of these areas.

Keywords: social conflict, protected area, social perceptions, Costa Brava, socioeconomic activities.

\section{Introduction}

In Spain, conservation policies launched to protect natural values during the 70 s and 80 s were characterised for the designation of natural protected areas in an isolated fashion. This perspective has evolved with the understanding that it is necessary to protect the functionality of these areas and therefore, the creation of a network of connected natural systems is basic. However, such conservation strategies can affect many socioeconomic activities such as agriculture, tourism and construction, which often lead to a number of social conflicts.

This paper presents the results of a research carried out in the designated area of $A i$ guamolls de l'Empordà, in the heart of Costa Brava (Spain), where a proposal to extend the perimeter of the protected area in order to guarantee the connectivity function of the territory has caused a local but severe social conflict. The main objective is to explore public perceptions regarding this intervention in order to deepen in the main causes of such social rejection. The research has collected the local opinion on the problem and the perception in front of the socioeconomic and environmental impacts of the proposal. It is basically an analysis on the institutional performance followed by a social perception study based on a qualitative survey applied to local stakeholders. 


\subsection{The case study}

The work has been conducted in Alt Empordà, which forms part of Costa Brava (Catalonia), a highly developed tourist area in the NE of the Spanish Mediterranean coast (See figure 1). The region's unique historical heritage and landscape, so different from the rest of the Spanish Mediterranean coastline, has, since the 60s provoked extremely intensive tourism development, which has focused on the region's 'sun and sand' resources. With the tourism boom, the growing pressure of a process of urbanisation of second home residences, the social use of these beaches has become more and more intensive. In particular, the coastline of the study area, traditional sun and beach uses coexist with nautical activities based on wind resource, such us kite and windsurfing.

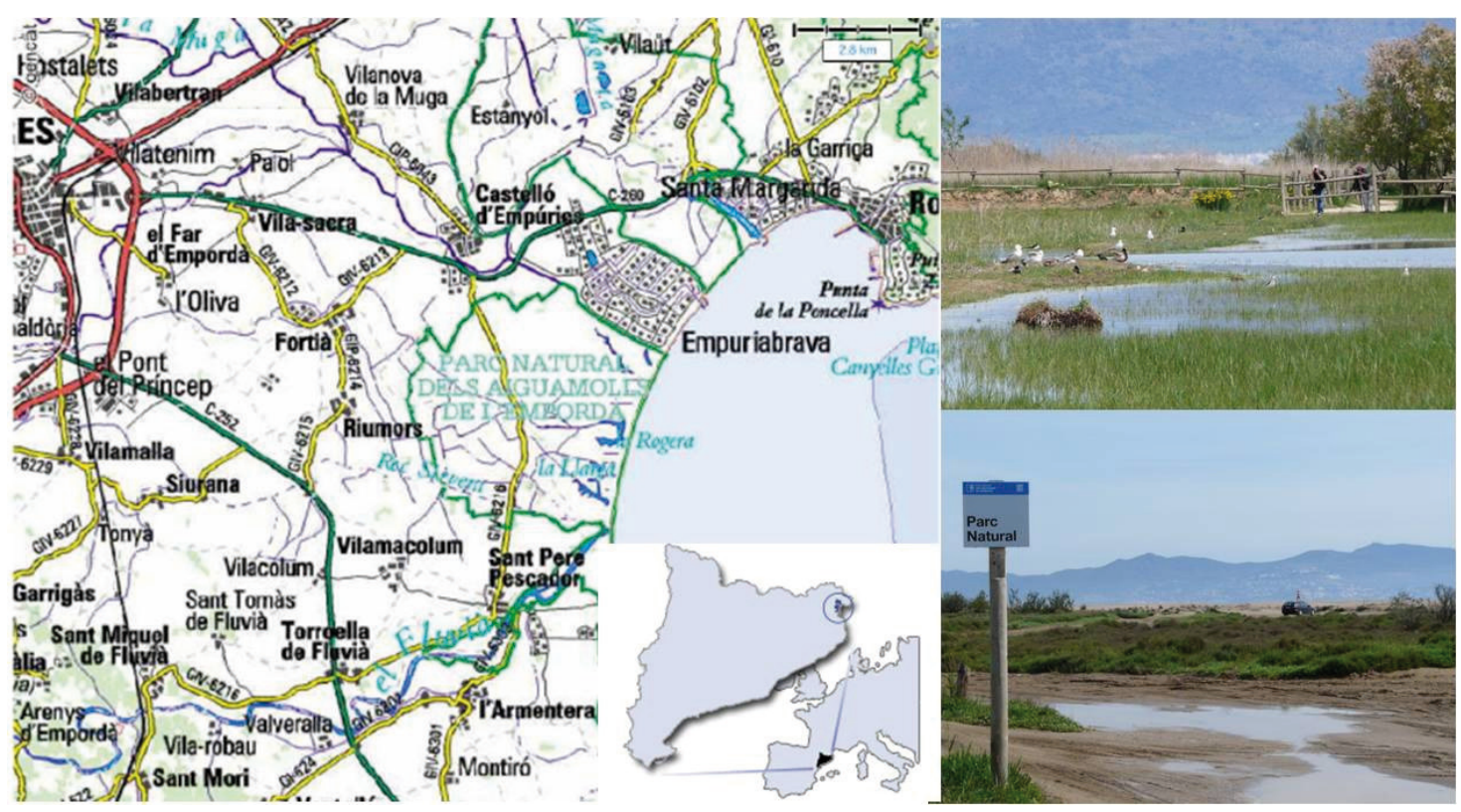

Fig.1. Location of study area

The aforementioned tourist and urban expansion occurs mainly in a period characterised by a lack of organisation and corrective actions of the public authorities, due to political or economic and speculative reasons. In this background and facing the imminent threat of urbanisation of one of the last areas of wetlands in Catalonia, one of the first environmental movements to safeguard Aiguamolls de l'Empordà appears. This, as explained below, ends with the regulatory protection of this space through the creation of Aiguamolls de l'Empordà Natural Park.

The Natural Area of Els Aiguamolls de l'Empordà is a set of marshes located in the Alt Empordà plain, which is generated, partly, by the final stretch of the river Muga and Fluvià. With an area of 4,824 hectares, they are the second most important wetlands in Catalonia (Spain) after the Ebre Delta. It is a typical landscape of the western Mediterranean coastal lowlands formed by sedimentary environments whose evolution has led to the existence of wetlands on their surface (Romagosa, 2007). 
The highly dynamic nature of these lowlands in relation to the sea level creates rich diverse and ecologically important habitats, but at the same time being very fragile and complex. The $10 \mathrm{~km}$ of shoreline includes lagoons, marshes, rows of dunes and beaches. All these diverse environments are a refuge for a wide range of animal species from which the birds deserve a special attention because of their abundance and diversity. The Aiguamolls de l'Empordà is the ideal place for shelter and food for migratory birds.

In spite of the values described, the natural balance of this area has been historically disturbed by the human activities e.g. creating dams, diverting rivers and draining and transforming the marshes. There is an extensive network of torrents, canals and irrigation ditches that have an important role in the drainage of periodically inundated lands, in the transport of water for irrigation and also in the regulation of the water level of certain crops. Between the Alt Empordà and Baix Empordà depression, there are more than $1000 \mathrm{~km}$ of canals that act as biological corridors connecting the different spaces of the region and giving cohesion to the area (Quintana et al., 2004). As a result, a significant portion of wetlands that once existed has disappeared, either by natural recession or by human transformation (Riba, 1977). The hinterland, far from marine influence and because of the ease they had to flood, has replaced the traditional crops with others of higher value and performance, such as rice.

Apart from these functions related to conservation -for its role as habitat and protection- and to agricultural production, the park and the surrounding area also offer a relevant and diverse recreational function. Each year the park receives thousands of visitors and its beaches are visited by sun and sand tourism and water sports enthusiasts. In a nominal way, local hunting preserves still maintain their hunting activity.

Recently, a proposal of the regional government to extend the boundaries of this natural protected area in order to ensure its connectivity with other natural areas has revived an old conflict, which is the object of this research.

\section{Methodology}

Firstly, a more static analysis based on local documents and press reviews enabled the identification of the main stakeholders and their relationships and to re-construct the background of the conflict. Secondly, a qualitative survey based on motivation analysis was launched. With a total of 15 in-depth interviews, social and local perceptions were outlined in a qualitative form. The interviewees came from different economic sectors (camping, tourism, agriculture), social and environmental groups (environmental and conservation associations, hunting associations), research institutions and administrative authorities (local and regional administrations) (Villares, 2006; Roca et al. 2008).

The interviews were carried out during the period of greatest conflict, from the announcement in the media of the park expansion at the end of 2008 to the end of the period of consutation of the regulatory document, in spring 2010. Finally, a content analysis of the in-depth interviews was performed to fully understand the questionnaire results.

\section{Results}

\subsection{Stakeholders' description}


The actors that are active in the case study have been identified and represented in Fig. 2 . They have been classified according to their interests and the nature of the entity they belong to.

Firstly, the Public Administration is represented at four levels (national, regional, supra-local and local), often with very different political positions and conflicts of interest. All this makes the task of managing this sector more complicated. If a list of institutions that have competence in this area is established, it can be observe how, at the state level, the Ministry of the Environment, Rural and Marine Affairs, through the General Directorate of Coasts is present in the area, as a part of the park is affected by the Coastal Law. At the regional level, the Generalitat of Catalonia is involved in the management of natural areas, the regional planning and the regulation of agricultural activity. More specifically, the competences fall on the Department of Environment and Housing, the Department of Planning and Public Works and the Department of Agriculture, Livestock and Fisheries respectively. At a lower territorial level, the Girona Provincial Council, the Alt Empordà Regional Council and the Governing Board of the Park, the managing body of this protected area is made up of representatives of the competent administrations and regional agents. At a local level, the town councils and their respective General Urban Plans are key actors in the conflict.

\begin{tabular}{|c|c|c|c|}
\hline \multicolumn{2}{|l|}{ Type of actor } & \multicolumn{2}{|l|}{ Actor } \\
\hline \multirow{4}{*}{$\begin{array}{l}\text { Public administra- } \\
\text { tion }\end{array}$} & National & \multicolumn{2}{|c|}{ Ministry of the Environment, Rural and Marine Affairs. General Directorate of Coasts. } \\
\hline & Regional & \multicolumn{2}{|c|}{$\begin{array}{l}\text { Department of Environment and Housing } \\
\text { Department of Planning and Public Works } \\
\text { Department of Agriculture, Livestock and Fisheries }\end{array}$} \\
\hline & Supra-local & \multicolumn{2}{|c|}{$\begin{array}{l}\text { Alt Empordà Regional Council } \\
\text { the Governing Board of the Park } \\
\text { Girona Provincial Council }\end{array}$} \\
\hline & Local & \multicolumn{2}{|c|}{$\begin{array}{l}\text { The Municipalities of Sant Pere Pescador, Castello d'empuries } \\
\text { Riumors, Palau-Saverdera, Peralada, Pau, Pedret i Marzá, L'Escala, Roses, L'Armentera. }\end{array}$} \\
\hline \multirow{2}{*}{\multicolumn{2}{|c|}{ Socioeconomic activities }} & Agriculture & Farmers Union and Cooperatives \\
\hline & & Tourism & $\begin{array}{l}\text { Camping Association of Sant Pere, the Tourist Board and nautical } \\
\text { beach activities agencies }\end{array}$ \\
\hline \multirow{3}{*}{\multicolumn{2}{|c|}{ Territorial Lobbies }} & Environmental values & $\begin{array}{l}\text { IADEN (The Alt Empordà Institution for the Study and Defense of Na- } \\
\text { ture }\end{array}$ \\
\hline & & Landowners & Let's Save Catalunya Platform \\
\hline & & Hunting & Association of Hunters of Castelló d'Empúries) \\
\hline \multicolumn{2}{|l|}{ Mass media } & Written press & $\begin{array}{l}\text { Diari de Girona } \\
\text { El Punt Girona }\end{array}$ \\
\hline \multicolumn{2}{|l|}{ Experts } & $\begin{array}{l}\text { Universities and re- } \\
\text { search centers }\end{array}$ & $\begin{array}{l}\text { Universidad de Girona } \\
\text { Centro de Estudios Avanzados de Blanes } \\
\text { Universidad Politécnica de Catalunya }\end{array}$ \\
\hline
\end{tabular}

Fig. 2. List of actors present in the study area 
The economic actors more present in the study area come from the agricultural sector (i.e. Farmers Union and Cooperative) and tourism (i.e. Camping Association of Sant Pere, the Tourist Board and nautical beach activities agencies). Moreover, the territory has erected a series of lobbies with very diverse interests. On the one hand, the entity IADEN (The Alt Empordà Institution for the Study and Defence of Nature) is leading the defence of environmental values. On the other hand, both hunting representatives (Association of Hunters of Castelló d'Empúries) as well as an entity that brings together landowners (Let's Save Catalunya Platform) have become the sector of society that generates more opposition to the planning proposal.

Finally, given the high environmental value of the area and the complexity of the natural processes that take place there, the expertise and information provided by scientists and technicians in the management of this area is considered relevant.

\subsection{Historical background of the conflict}

The origin of the conflict started in the early seventies, when a residential marina was planned to be placed between the Muga and Fluvià, a continuation of the expansion that began with the construction of the macro housing development in Empuriabrava. This serious threat in the area of Aiguamolls de l'Empordà generated a very active advocacy movement promoted by the environmental and naturalist sectors of Catalonia. In July 1977, the company Port Llevant Inc. began working on an road of access to the urban site, but the Directorate General of Artistic and Cultural Heritage ordered the stoppage of works for acting on a picturesque site without requesting permission. In 1978 the issue was passed to the Autonomous Government, who commissioned a report which concluded that the region had a great interest and deserved to be protected. At the same time, the urban plan of Port Llevant was invalidated.

Subsequently, there were several attempts to create a protection figure for Els Aiguamolls until 1983, when the Parliament of Catalonia unanimously approved the Law 21/1983 of October 28th and declared Els Aiguamolls de l'Empordà a Natural Area of National Interest and Zoological and Botanical Integral Reserve. A year later, the Catalan Government bought the building owned by Port Llevant which was an important step towards the consolidation of the protected space.

This overlaps in time with major urbanisation of the Catalan coast, where large tracts of agricultural land were reassessed and declared urban land assigned for tourism and second homes. Therefore, despite the numerous demonstrations and the collection of signatures that occurred during this period in favour of protecting Els Aiguamolls, there was also a group that was against the Park and for the development of Port Llevant's project, given the economic benefit that could entail.

While the status of the Natural Park has the aim of reconciling human activities with the maintenance of environmental values or the promotion of contact between society and the environment (Carceller, 1986), in the case of the management of the Aiguamolls de l'Empordà Natural Park. This compatibility has always been an element of conflict. From the initial reticence of some segments of the population in the vicinity of the Park to date, the clashes followed one after another, triggered by the conservationist zeal for issues such as tree felling, hunting, water level and the reintroduction of species... On the other hand, the aid re- 
ceived by the Park in some aspects (i.e. plagues), grants and technical collaborations tried to calm the conflict.

In late 2008, the will to increase the ecological connectivity of this space encouraged the Department of the Environment and Housing of the Catalan Government to propose an extension to the park which affected a major expanse of agricultural land. Again, this reactivated the conflict in the area. Soon there were criticisms of this plan's approval. Specifically, in March 2009, the majority of the mayors of the municipalities affected by the Park were concerned about the negative effects of the Special Plan on agriculture and its future development. Subsequently, several farmers of the area criticised the plan for being too restrictive, especially regarding the crops and extensions of old buildings.

During 2009, the mayors affected by the Plan met several times and drafted a text which was approved in the plenaries by the respective town councils and was later supported by the Alt Empordà Regional Council. This text rejected the extension of the park pointing out that there were already agrarian areas of great importance within the existing park boundaries that had not been taken into account in recent years.

The Catalan Government considered amending this draft because of the contrary reactions that arose. Finally, a new plan proposal was created by reducing the peripheral areas of protection. Under this new proposal, the Plan would regulate about 7,000 ha. rather than the 10,000 originally planned.

On April 14th 2010, the announcement of the public information phase of the Special Plan of Natural Environment Protection and the Landscape of Aiguamolls de l'Alt Empordà was published in the Official Journal of the Generalitat of Catalonia (DOGC. 5607, April 14th, 2010). In late spring 2010 it underwent a public information phase.

At the same time, the study area was affected by other previous and different plans. At a supra-municipal level we find the Empordà's Director Plan (2006), which provides the strategic guidelines for regional planning in the area and the Urban Master Plan of the Coastal System (2005), which prevents the occupation of the non-urbanised areas in the coastal strip. At a municipal level there are the Municipal Urban Managing Plans with the urbanistic guidelines of each municipality and Plans of Beach Uses which order the activities that take place in the Terrestrial Maritime Public Domain.

\subsection{Conflict Analysis}

Since the origin of the designation Aiguamolls de l'Empordà as a protected area in 1986, the territorial relationship with the park has been very complicated. It must be taken into consideration that this is a region subject to a very intense process of growth, urban development and tourism. This model of sun and sand tourism so characteristic of the north-western Mediterranean has historically caused great strains on the coastal areas of great ecological value and on agricultural production lands. This case study is just another example of this revival of the conflict and now shows that the past experience has not helped to ease these tensions, rather the opposite. Thus, understanding the current conflict implies knowing the social perceptions of the actors most affected by the proposed new extension. A perception that has been built based on past experiences of a difficult coexistence with the park and fearing the impact that may occur on the socio-economic activities in the region. 
Agriculture is one of the most affected sectors and probably the most opposed to the Natural Park. In this sector, and greatly affected by processes beyond the local scale, one sees the park as an obstacle to developing their business and, above all, as a loss of a future opportunity to change their land use to other more economically profitable. Moreover, some actions taken by park managers are blamed for contributing to the deterioration of the quality and balance of its natural systems. In particular, the reintroduction of species, the water management, the limitation on certain crops or hunting restrictions have been criticised. In this sector, the most opposition to the proposal has been spearheaded by affected landowners represented by the Let's Save Catalonia Platform. The limitations or prohibitions affecting a property owner are seen as an imposition and an attack on the rights of private property. With a moderate attitude, the more institutional representatives of agriculture (cooperatives and unions) understand that the solution requires dialogue, collaboration and they defend a new appreciation of farmers. Beyond their productive activity, they claim the evaluation of their role in the protection of landscape and the function of ecological and territorial connectivity is important.

In the coastal zone, where we find most recreational uses associated with the beach resource, the owners of tourist facilities (campsites) and water sports dealers agree on the need to maintain environmental quality, attracts tourists. However, this sector has the perception that the park's conservation policy is at the expense of limiting and reducing its activity and thus compromising their future. This perception is based on a previous experience where the affectation of the park caused the loss of usable floor area of some campsites with no compensation. It also became complicated by the adequacy of the beach accesses and the creation of corridors to improve the connectivity between the coast and the agricultural areas near campsites. On the other hand, some campsites that occupy the Maritime Terrestrial Public Domain are in the process of expropriation of the affected area and their desire is to maintain their capacity by growing inward. However, the presence of the park does not allow it. On the beaches, the performance of the protected area includes the prohibition of the mechanical cleaning of sand in a large deltaic area, the installation of wooden walkways for disabled access, no access to the beaches at certain times of year, the reduction of available area for concessions and the regulation of water sports. All these problems contribute to increase the general perception in this sector that the presence of the park is more a constraint than an advantage.

These tourist and recreational activities, both those developed on the beach and in the hinterland, claim recognition that their activity also contributes to the protection of the area, both because they develop a soft activity on the territory as well as attracting a type of conscious and responsible tourist.

Despite the diversity of positions among the respondents, there is a shared vision: the park has been an island inside the region. Some respondents unilaterally blame the park for this situation by its strict conservation policy and the lack of dialogue and participation. Local governments recognize that they have lived with their back turned to the park. It has essentially opted for a sun and sand tourism and has not been able to find synergies with other forms of tourism that would come to the park in search of nature. At the same time, both park and municipal bodies budget limitations has hindered these relationships, the creation of stable and constant participation spaces.

\section{Conclusions}


The article discusses an issue that is often reproduced when implementing conservation strategies in the territory. The conflict of interest between conservation and development is accentuated in the coastal area because of the high competence of uses.

Institutional and perception analysis in the case of the extension of Aiguamolls de l'Empordà shows that the past management of the park was carried out in an isolated way, excluding the rest of the territory. This fact has generated suspicion and rejection of future actions. The lack of dialogue between institutions and local activities, this area's planning overlap and the historical ineffectiveness of the Managing Board have fuelled the conflict. On the other hand, despite the landscape, ecological and connectivity value that is given to agricultural land, the role of this sector regarding the conservation of these values is not recognized and has not been able to integrate it in their management. In the same way, the tourism sector does not regard the protection of territory as an asset that can benefit its business. Therefore, it is necessary to look for capabilities to combine attractives and complicities between the model of sun and sand tourism and green tourism, both present in the area but which ignore each other.

Conclusions indicate that a management model is required which encourages participation and dialogue and a stable and continuous cooperation of the different agents in the territory. This has to facilitate greater integration of socio-economic activities in a setting with great environmental values.

\section{References}

Carceller, X. 1986. Els parcs naturals com a factor de promoció sòcio-econòmica. Banca Catalana. Revista económica, Núm. 79. pp. 1-10.

Quintana, X., Gesti, J. and M. Marí, 2004. Recs i rieres. Aiguamolls del Baix Ter. Papers del Montgrí, Núm.23, 2004. pp. 150-153.

Riba, O. 1977. Ocupem els aiguamolls. Presència, 474. pp. 15-17.

Romagosa, F. 2007. Les funcions de les zones humides. Soldó, Núm.28, 2007. pp. 25.

Roca, E., Riera, C., Villares, M., Fraguell, R., Junyent, R. 2008. A combined assessment of beach occupancy and public perceptions of beach quality. A case study in the costa brava, spain. Ocean \& Coastal Management, 51 (12), 839-846.

Villares, M, Roca E., Serra, J. y Montori, C. 2006. Social perception as a tool for beach planning: a case study on the catalan coast. Journal of Coastal Research, SI 48: 188-123.

\section{Acknowledgement}

This research was carried out within the framework of the Defcon-EEP, under contract REN2003-09029-C03/MAR funded by the Spanish Ministry of Education and Science. 